\title{
PEDAGOGICZNO-KATECHETYCZNE MOŻLIWOŚCl ZASTOSOWANIA TEORII POWSTANIA ŻYCIA HOIMARA VON DITFURTHA
}

Kim jestem? Skąd przychodzę i dokąd zmierzam?, to uniwersalne i ponadczasowe pytania egzystencjalne, na które człowiek od wieków próbuje znaleźć odpowiedź1. Problematyka powstania życia (abiogeneza) nurtuje umysły wielu ludzi, zarówno filozofów, jak i teologów². Doczekała się wielu opracowań, tak na płaszczyźnie ewolucjonizmu

* Kierownik Zakładu Pedagogiki Pastoralnej na Wydziale Teologicznym Uniwersytetu Mikołaja Kopernika w Toruniu, profesor nadzwyczajny w Wyższej Szkole Komunikacji Społecznej w Gdyni, doktorat z pedagogiki (UG) i teologii (UKSW), doktor habilitowany nauk teologicznych, www.cichosz.pl.

** Zastępca Dyrektora Wydziału Duszpasterstwa Młodzieży Kurii Metropolitalnej Gdańskiej, duszpasterz i katecheta.

${ }^{1}$ Zob. W. Cichosz, Pedagogia wiary we wspótczesnej szkole katolickiej, Warszawa 2010, s. 221.

${ }^{2}$ Zob. tenże, Przypadek $i$ konieczność w egzobiologii, w: Egzobiologia czyli poszukiwanie życia w Kosmosie, red. W. Dyk, Szczecin 2002, s. 111-114. 
(przyrodniczej) $^{3}$, jak i kreacjonizmu (teologicznej) $)^{4}$. Wśród licznych koncepcji zdecydowanie wybija się teoria niemieckiego profesora psychiatrii i neurologii - Hoimara von Ditfurtha (1921-1989), twórcy uniwersalnej koncepcji Wszechświata na poziomie filozoficznym ${ }^{5}$. Jej głównym celem jest przede wszystkim wypracowanie porozumienia i dialogu ze współczesną teologią. To oryginalne ujęcie, godzące myśl teologiczną z filozoficzną refleksją i naukowym doświadczeniem, decyduje o jego ważności z punktu widzenia światopoglądu chrześcijańskiego, zwłaszcza w dziedzinie edukacyjnej i formacyjnej, katechetycznej i pastoralnej.

Przydatność koncepcji tego typu mierzy się zarówno tkwiącymi w nich wartościami naukowymi, jak i pewnym rodzajem właściwie rozumianego "pragmatyzmu”, a więc możliwością ich wykorzystania w obszarze edukacji, szczególnie wychowania w wierze. Wielu spośród współczesnych młodych ludzi w wieku szkolnym orientuje się w wybranych naukach szczegółowych, między innymi chemii, fizyce i biologii. Jednocześni ci sami pasjonaci przyjmują niekiedy, że współczesny obraz świata - powstały dzięki naukowym faktom i ich interpretacji - jest przeciwny obrazowi świata wyłaniającego się z teologii Kościoła. To zjawisko charakteryzuje nie tylko młodzież szkolną, lecz i młodych naukowców. Czasem nawet i sami rodzice, nauczyciele i katecheci, niezbyt jasno rozumieją korelację między nauką i wiarą. Właśnie z myślą o nich istnieje potrzeba wyjaśnienia tej kwestii. Stworzenie i ewolucja są

${ }^{3}$ Ewolucjonizm to pogląd, według którego struktura rzeczywistości i jej stan teraźniejszy mogą być wyjaśnione tylko jako rezultat ewolucji, której podlegają przedmioty i zjawiska. Por. T. Styczeń, Ewolucjonizm, w: Encyklopedia Katolicka, t. 4, red. A. Szostek, Lublin 1995, s. 1450-1460. Zob. także: W. Dyk, Rola praw biologicznych w wyjaśnianiu ewolucyjnym, Szczecin 1998; R. Lewin, Wprowadzenie do ewolucji człowieka, tłum. A. J. Tomaszewski, Warszawa 2002.

${ }^{4}$ Por. K. Kloskowski, Zagadnienie determinizmu ewolucyjnego. Studium biofilozoficzne, Gdańsk 1990. Klasyczna definicja kreacjonizmu (Rdz 1,1-2,4), przyjęta na pierwszych soborach powszechnych, głosiła, że "creatio est productio entis (rei) ex nihilo sui et subiecti - stworzenie jest powołaniem do istnienia rzeczy z nicości jej samej i z nicości podłoża (niejako «bez niczego», co pełniej ukazuje zależność od Bytu Bożego)" - P. Janowski, J. Krasiński, Kreacjonizm, w: Encyklopedia katolicka, t. 9, red. A. Szostek, Lublin 2002, s. $1237-1249$.

${ }^{5}$ Udaną i ciekawą próbę prezentacji katechetyczno-duszpasterskich implikacji koncepcji Hoimara von Ditfurtha podjął ks. Krzysztof Gidziński w wyróżnionej przez recenzentów pracy magisterskiej przedstawionej na Wydziale Teologicznym Uniwersytetu Kardynała Stefana Wyszyńskiego w Warszawie: K. Gidziński, Katechetyczne możliwości zastosowania teorii powstania życia Hoimara von Ditfurtha, Warszawa 2011, ss. 81 (maszynopis). 
dwoma aspektami tej samej rzeczywistości, poznawanej na drodze nauk przyrodniczych i teologicznych ${ }^{6}$.

\section{POWSTANIE WSZECHŚWIATA}

Specyfika koncepcji powstania życia autorstwa Hoimara von Ditfurtha domaga się przedstawienia pojęcia, które stoi u jej podstaw - ewolucji. Termin ten pochodzi od łac. evolutio i oznacza rozwój. Jest to „stopniowy i ciągły proces przemian, polegający na przejściu ze skupiska niezróżnicowanego w zróżnicowane lub z mniej zróżnicowanego w bardziej zróżnicowane, a dokonujący się według własnych praw na drodze przyswajania sobie elementów obcych i przystosowywania się do konkretnych warunków"7. Osadzenie przez Karola Darwina pojęcia ewolucji na gruncie biologii nadało mu "charakter procesu przekształcenia organizacji i sposobu życia organizmów, prowadzącego do różnic potomstwa od jego przodków"8. Hoimar von Ditfurth przeniósł koncepcję Darwina, zajmującą się tylko światem ożywionym, na materię w ogólności. Nadaje ewolucji rangę koncepcji tłumaczącej rozwój całego świata: „Zjawisko ewolucji istnieje nie tylko na obszarze tego, co żywe. Istnieje także ewolucja kosmiczna" W swoich dociekaniach zagłębia się w kosmogenezę i tam doszukuje się pierwszych mechanizmów ukierunkowanych zmian materii. To one doprowadziły do powstania gwiazd, galaktyk, układów planetarnych i samych planet, które stały się środowiskiem optymalnym dla biogenezy.

Obecny stan Wszechświata naukowcy tłumaczą posługując się głównie dwiema teoriami kosmologicznymi: teorią stanu stacjonarnego i teorią wielkiego wybuchu ${ }^{10}$. Pierwsza z nich głosi, że Wszechświat

${ }^{6}$ Zob. K. Kloskowski, Między ewwolucją a kreacja, Warszawa 1994; K. Dziadkowiak, Czy teoria ewolucji jest do zbawienia koniecznie potrzebna? Czyli jak mądrze mówić z młodzieża o wierze i nauce, „Katecheta” 2011, nr 2, s. 57-61.

7 A. Podsiad, Z. Więckowski, Mały stownik terminów i pojęć filozoficznych, Warszawa 1983, s. 97.

8 Tamże.

${ }^{9} \mathrm{H}$. von Ditfurth, Nie tylko z tego świata jesteśmy. Nauki przyrodnicze, religia i przyszłość człowieka, tłum. A.D. Tauszyńska, Warszawa 1985, s. 23.

${ }^{10}$ Por. S. G. Brush, Jak kosmologia stata się nauka, tłum. M. Krośniak, „Świat Nauki” 1992, nr 10, s. 36-44. O innych próbach wyjaśnienia genezy Wszechświata pisali m.in.: J.J. Halliwell, Kosmologia kwantowa $i$ stworzenie Wszechświata, tłum. K. Maślanka, „Świat Nauki" 1992, nr 2, s. 28-37; D. N. Spergel, N.G. Turok, Tekstury i struktura Wszechświata, tłum. Z. Loska, „Świat Nauki” 1992, nr 5, s. 40-48. 
istnieje od zawsze, a ubytek materii wynikający z obserwacyjnie potwierdzonego rozszerzania się Wszechświata jest kompensowany w procesie nieustannego stwarzania. H. von Ditfurth opowiada się za drugą teorią, najlepiej dotąd potwierdzoną badaniami astronomicznymi ${ }^{11}$. Zasadnicza jej teza brzmi: „Wszechświat miał swój początek”"12. Przed około 13 miliardami lat ${ }^{13}$ cała materia Wszechświata była skoncentrowana w jednym punkcie $^{14}$ - o nieskończenie małej objętości i nieskończenie wysokiej temperaturze - zwanym "początkową osobliwością"15, od którego mierzy się czas $^{16}$. Jądro o niewyobrażalnej gęstości eksplodowało, rozrzucając materię z prędkością światła. Pozostałości tego wydarzenia zauważa się obecnie $\mathrm{w}$ zjawisku promieniowania reliktowego ${ }^{17}$, dochodzącego do Ziemi ze wszystkich stron w zakresie fal milimetrowych. Potwierdzeniem rozszerzania się Wszechświata jako całości jest rejestrowane przesunięcie ku czerwieni linii widmowych ${ }^{18}$ wypromieniowanych przez gwiazdy jako efekt ucieczki galaktyk ${ }^{19}$, oddalających się wzajemnie od siebie w tempie proporcjonalnym do ich odległości ${ }^{20}$. Faza gwałtownej ekspansji Wszech-

${ }^{11}$ Por. K. Maślanka, Obrona Wielkiego Wybuchu, „Wiedza i Życie” 1991, nr 11, s. 22-27. Zob. także: tenże, Uniewinnienie Wielkiego Wybuchu, „Wiedza i Życie” 1992, nr 9, s. 66-70; C.S. Powell, Ztoty wiek kosmologii, „Świat Nauki” 1992, nr 9, s. 6-12.

${ }^{12} \mathrm{H}$. von Ditfurth, Na poczatku był wodór, tłum. A. D. Tauszyńska, Warszawa 1989, s. 69; Tenże, Dzieci Wszechświata, tłum. A. D. Tauszyńska, Warszawa 1990, s. 375.

${ }^{13}$ Por. tenże, Na początku byt wodór, s. 75. O problemie ustalenia początku Wszechświata w czasie (10-20 miliardów lat temu): W. L. Freedman, Szybkość rozszerzania się i rozmiary Wszechświata, tłum. M. Krośniak, „Świat Nauki” 1993, nr 1, s. 34n.

${ }^{14}$ Por. H. von Ditfurth, Na początku byt wodór, s. 70.

${ }^{15}$ Nazwa ta bierze się stąd, że wszystkie historie cząstek elementarnych i promieni świetlnych, rozpatrywane wstecz kończą się w momencie, gdy cała materia Wszechświata jest upakowana nieskończenie gęsto i gdy tzw. wielkim wybuchem rozpoczyna się proces kosmicznej ekspansji. Por. M. Heller, M. Lubański, Sz. Ślaga, Zagadnienia filozoficzne wspótczesnej nauki. Wstęp do filozofii przyrody, Warszawa 1982, s. 246.

${ }^{16}$ Por. tamże, s. 240n.

${ }_{17}$ Jest to promieniowanie elektromagnetyczne, które zgodnie $\mathrm{z}$ teorią wielkiego wybuchu, wraz z materią skupioną w galaktykach wypełnia przestrzeń wszechświata; jego rozkład widmowy jest bliski rozkładowi promieniowania ciała doskonale czarnego o temperaturze ok. 3 Kelwinów. Por. H. Ditfurth, Na początku byt wodór, s. 41.44.

${ }^{18} \mathrm{O}$ poszukiwaniu śladów fal grawitacyjnych w mikrofalowym promieniowaniu tła MPT, tzw. promieniowaniu reliktowym: R. Caldwell, M. Kamionkowski, Echa Wielkiego Wybuchu, tłum. M. Demiański, „Świat Nauki” 2001, nr 3, s. 22-27.

${ }^{19}$ Por. H. Ditfurth, Na początku byt wodór, s. 67n; tenże, Nie tylko z tego świata jesteśmy, s. 23.

${ }^{20} \mathrm{O}$ metodach wyznaczania odległości i ustalania prędkości oddalania się galaktyk: W.L. Freedman, Szybkość rozszerzania się i rozmiary Wszechświata, s. 28-35. 
świata zwana inflacją ${ }^{21}$ charakteryzowała się jednoczesnym obniżaniem się temperatury i gęstości materii w przeciągu krótkich ułamków sekundy ${ }^{22}$.

Pierwszym i najlżejszym pierwiastkiem wyłonionym z początkowego wielkiego wybuchu był wodór ${ }^{23}$. Gdy temperatura materii spadła do rzędu setek milionów stopni, powstały warunki sprzyjające syntezie wolnych protonów i neutronów w jądro helu ${ }^{24}$. Synteza jąder atomowych w kolejne cięższe pierwiastki postępowała już w środowisku wnętrza gwiazd $^{25}$. Rozproszona materia zaczęła wykazywać niejednorodność, skupiając się w poszczególnych miejscach ${ }^{26}$. Gigantyczne obłoki gazowego wodoru zapadły się w sobie pod wpływem własnych wewnętrznych sił przyciągania. Pojawiły się zarodki wielu miliardów galaktyk ${ }^{27}$, kurczące się w kierunku swego punktu ciężkości i przyjmujące kształt zbliżony do $\mathrm{kuli}^{28}$. Pod wpływem ruchu obrotowego siła odśrodkowa w przeciągu wielu setek milionów lat ${ }^{29}$ sprowadzała obłoki do kształtu dysków o średnicy liczącej setki tysięcy lat świetlnych ${ }^{30}$. Już w fazie wchodzenia obłoku w ruch obrotowy - przed około 10 miliardami lat - niemal z czystego wodoru $^{31}$ powstawały pierwsze gwiazdy ${ }^{32}$. Najstarsze $\mathrm{z}$ nich tworzyły

${ }^{21}$ Por. M. Heller, M. Lubański, Sz. Ślaga, Zagadnienia filozoficzne wspótczesnej nauki, s. 240 .

${ }^{22}$ Dokładniej o poszczególnych fazach ekspansji Wszechświata: S.W. Hawking, Krótka historia czasu. Od wielkiego wybuchu do czarnych dziur, tłum. P. Amsterdamski, Warszawa 1990, s. 112-134. Por. także: M. Heller, M. Lubański, Sz. Ślaga, Zagadnienia filozoficzne wspótczesnej nauki, s. 238-241.

${ }^{23}$ Por. H. von Ditfurth, Na początku byt wodór, s. 126.

${ }^{24}$ Por. tenże, Nie tylko z tego świata jesteśmy, s. 24.

${ }^{25}$ Por. tenże, Dzieci Wszechświata, s. 29.

${ }^{26}$ W kwietniu 1992 roku, po przeanalizowaniu wyników badań prowadzonych za pomocą satelity COBE, wykryto drobne fluktuacje promieniowania reliktowego potwierdzające powstanie galaktyk, ich gromad oraz gwiazd i planet według teorii wielkiego wybuchu. Zob. K. Maślanka, Uniewinnienie Wielkiego Wybuchu, s. 68. O wielkoskalowym rozkładzie materii we Wszechświecie: A. Dressler, Wielki Atraktor, „Problemy” 1991, nr 8, s. 45-53. Zob. także: M. Różyczka, COBE dwa lata później, „Wiedza i Życie” 1994, nr 4, s. 15-19; M. Demiański, Nowy wspaniaty Wszechświat, „Wiedza i Życie” 1999, nr 6, s. 34-37.

${ }^{27}$ Badania astronomiczne i symulacje komputerowe potwierdziły taką możliwość. Zob. R. Tresch Fienberg, Wszechświat bąbli i pustek, tłum. K. Stanek, „Problemy” 1991, nr 2-3, s. 51-52.

${ }^{28}$ Por. H. von Ditfurth, Dzieci Wszechświata, s. 375.

${ }^{29}$ Por. tenże, Nie tylko z tego świata jesteśmy, s. 27.

${ }^{30} \mathrm{O}$ innej próbie wyjaśnienia powstania galaktyk: E. Vishniac, Paragrawitacja, czyli jak powstaty galaktyki, tłum. D. Kapiszewska, „Problemy” 1990, nr 9, s. 50-52.

${ }^{31}$ Por. H. von Ditfurth, Dzieci Wszechświata, s. 364.

${ }^{32}$ Por. tenże, Nie tylko z tego świata jesteśmy, s. 28. 
tak zwane „gromady kuliste”33, czyli koncentrację kilkuset tysięcy lub też milionów gwiazd w kuli o średnicy kilkuset lat świetlnych. Poruszały się one - w odróżnieniu od wszystkich innych później powstałych gwiazd niezależnie od ruchu obrotowego całej galaktyki. Powstała więc pierwsza generacja gwiazd, a gdy ich gęstość okazała się wystarczająca, by uruchomić w ich wnętrzu reakcje atomowe - pojawiły się nowe pierwiastki.

Przez miliardy lat we wnętrzu gwiazd zachodziły przemiany wodoru $\mathrm{w}$ hel, następnie helu $\mathrm{w}$ węgiel, tlen i inne pierwiastki ${ }^{34}$. Gwiazdy ginęły w potężnych eksplozjach supernowych ${ }^{35}$, dzięki którym nowe pierwiastki pod postacią drobno rozproszonego pyłu wypełniały wolną przestrzeń w obrębie układu galaktycznego. Ze wzbogaconej cienkimi pierwiastkami materii gwiazdowej wyłoniło się nowe pokolenie gwiazd, które kontynuowało ten proces i uzupełniło liczbę pierwiastków. Proces powstawania pierwiastków rozgrywał się przez szereg następujących po sobie pokoleń gwiazdowych, z których jedno zawsze powstawało z materii przekazanej mu przez pokolenie poprzednie. $W$ toku owej kosmicznej przemiany pokoleń cała materia występująca w mgławicach spiralnych wciąż od nowa zgęszczała się w gwiazdy, by następnie ponownie powrócić do wolnej przestrzeni kosmicznej. Jak podaje H. von Ditfurth: „Stopniowo wytworzyły się pozostałe pierwiastki układu okresowego, aż po najcięższy - uran. Wreszcie przed około 5 miliardami lat uformowały się gwiazdy o materii zawierającej po raz pierwszy wszystkie pierwiastki, jakie mogły występować trwale na Ziemi"36.

\section{PRZEJŚCIE EWOLUCJI CHEMICZNEJ W EWOLUCJĘ BIOCHEMICZNĄ}

Ziemia, trzecia planeta Układu Słonecznego, stała się sceną, na której rozegrały się procesy ewolucji materii. Coraz bardziej zróżnicowane związki chemiczne - pod wpływem działania atmosfery ziemskiej i promieniowania słonecznego - dały początek nowej jakości przemian. Hoimar von Ditfurth przedstawia to wydarzenie jako wyłonienie się ze środowiska chemicznego budulców organicznych, z których bezpośrednio

33 Tamże, s. 25.

${ }^{34}$ Por. tenże, Dzieci Wszechświata, s. 378.

${ }^{35} \mathrm{O}$ cyklu ewolucyjnym gwiazd: N. Soker, Mgtawice planetarne, tłum. Z. Loska, „Świat Nauki” 1992, nr 7, s. 52-60.

${ }^{36}$ H. von Ditfurth, Dzieci Wszechświata, s. 379. 
powstało życie. Wraz ze zmianami skorupy ziemskiej postępował rozwój jej powłoki gazowej, czyli atmosfery. Pierwotna atmosfera Ziemi nie zawierała wolnego tlenu, obfitowała natomiast w parę wodną, wodór, azot, dwutlenek węgla, metan, amoniak i inne gazy - dostarczone przez procesy wulkaniczne. Dzięki temu wielkocząstkowe struktury, które zaczęły się pojawiać, miały sprzyjające warunki rozwoju, gdyż nie zagrażało im natychmiastowe utlenienie. Ogromne ilości pary wodnej ulegały skraplaniu, dając początek pierwotnej hydrosferze - woda stała się „kolebką i początkiem życia" ${ }^{37}$. Stało się to możliwe dzięki ochłodzeniu skorupy ziemskiej na tyle, że woda spadająca z przesyconej parą wodną atmosfery już natychmiast nie wyparowywała, lecz gromadziła się w formie ciekłej, tworząc przed mniej więcej 4,5 miliardami lat praoceany.

Brak tlenu w pierwotnej atmosferze stanowił prawdopodobnie nieodzowny warunek do powstania związków, służących za budulce dla życia. Tlen pełnił bowiem rolę filtra atmosferycznego, zatrzymującego promieniowanie ultrafioletowe Słońca. Wysyłane przez Słońce promieniowanie swobodnie docierało do powierzchni Ziemi, gdzie w płytkich wodach gromadziły się związki nieorganiczne. Fotony promieniowania ultrafioletowego dostarczyły „energii potrzebnej do powiązania nieorganicznych związków w wielkie cząsteczki, między innymi węglowodory i aminokwasy - biologicznie najważniejsze elementy budulcowe życia"38. Proste związki obecne w dużych stężeniach na powierzchni wszystkich wód stojących (do 15 metrów w głąb) w wyniku reakcji fotochemicznych gromadziły się w wielkie cząsteczki i opadały w głębsze warstwy wody. Tam promieniowanie traciło swą moc oddziaływania, gdyż wyższe warstwy wody zaczęły pełnić rolę filtra. Wielkie cząsteczki prostych związków nieorganicznych gromadziły się na takiej głębokości, do której promieniowanie słoneczne już nie docierało. Jednocześnie na powierzchni praoceanów energia promieniowania ultrafioletowego rozszczepiała cząsteczki wody na wolny wodór i wolny tlen. Zjawisko to nazwano fotodysocjacją wody ${ }^{39}$. Uwolniony wodór unosił się w przestrzeń kosmiczną, zaś tlen pozostał i zbierając się w atmosferze, osiągnął wreszcie stężenie 0,1 procenta, wystarczające do zatrzymania promieniowania ultrafioletowego. Proces dysocjacji uległ zahamowaniu. Skoro zaś stężenie tlenu w atmosferze znowu spadło (np. przez utlenianie na powierzchni) na

\footnotetext{
37 Tamże, s. 21.

${ }^{38}$ W. Kinastowski, Podstawy biologii wspótczesnej, Warszawa 1974, s. 411.

${ }^{39}$ Por. H. von Ditfurth, Na początku byt wodór, s. 120.
} 
nowo rozpoczynał się pod wpływem działania światła rozpad cząsteczek wody. Ten decydujący etap ewolucji atmosfery ziemskiej - przebiegający według zasady sprzężenia zwrotnego - naukowcy nazwali „efektem Ureya" ${ }^{\prime 40}$. W jego wyniku makrocząsteczki były chronione przed ponownym rozpadem ${ }^{41}$, i tym samym faza cyklicznego budowania i rozpadu zakończyła się. Przed 4 miliardami lat tlen stworzył filtr, stanowiący skuteczną "zasłonę dla fal elektromagnetycznych o długości od 2600 do 2800 angstremów. Jest to dokładnie ten zakres promieniowania, który niszczy białka i kwasy nukleinowe - biopolimery mające niebawem się pojawić" ${ }^{42}$.

$\mathrm{Z}$ mieszaniny cząsteczek wody, dwutlenku węgla, metanu, wodoru i amoniaku zgromadzonych przy powierzchni praoceanów - pod działaniem promieniowania ultrafioletowego i potężnych wyładowań elektrycznych (błyskawic) - powstawały związki aminokwasów. Kombinacje cząstek, wielokrotnie łączonych i rozbijanych, dały w ciągu kilku milionów lat początek dwudziestu aminokwasom o znaczeniu biologicznym, co potwierdziły doświadczenia S. Millera i W. Foxa ${ }^{43}$. Ewolucję na poziomie molekularnym przyspieszyły enzymy, czyli białka zdolne do katalizy reakcji chemicznych, nie wiążąc się z nowo powstałym związkiem, nie ulegając przemianie i nie zużywając energii. Swoistość ich działania jest zakodowana w sekwencji aminokwasów. Enzymatycznie katalizowane reakcje stały się podłożem przemiany materii - czyli całego zespołu procesów, które decydują o życiu. Dzięki nim organizm zbudowany ze związków chemicznych wykazuje przejściową całość, mimo że w nim samym oraz pomiędzy nim a otoczeniem w ogromnej liczbie i z wielką szybkością zachodzą reakcje chemiczne.

Poziom molekularny stał się ostatecznym podłożem wszystkich żyjących organizmów, gdyż komórka jest w pewnym sensie aparatem molekularnym, stanowiącym autonomiczną jednostkę funkcjonalną. Okazało się to możliwe dzięki sprzężeniu zwrotnemu między enzymami a kwasem dezyksorybonukleinowym (DNA). Kwasy nukleinowe sterowały wytwarzaniem enzymów i innych białek, z kolei enzymy budowały białka oraz kwasy nukleinowe. Samoutrzymujące się struktury molekularne - utworzone przez zamknięty obieg kwasów nukleinowych i białek

\footnotetext{
40 Tamże, s. 121.

${ }^{41}$ Por. W. Kinastowski, dz. cyt., s. 413.

${ }^{42} \mathrm{H}$. von Ditfurth, Na początku byt wodór, s. 123.

${ }^{43}$ Zob. W. Kinastowski, dz. cyt., s. 419-421.
} 
- zostały wyodrębnione z otoczenia. Środowisko wyizolowało układy, w których mechanizm białko-DNA najdłużej pozostawał nienaruszony. Pojawiały się one w coraz większej ilości i coraz to doskonalsze. Były to prawdopodobnie mikroskopijne mieszanki białka i kwasów nukleinowych otoczone błoną, która przepuszczała drobne cząsteczki, niezbędne jako surowce i źródło energii, a jednocześnie osłaniała przed szkodliwymi wpływami z zewnątrz. Związki takie otaczały się cienką powłoką wodna, a elektryczne ładunki powierzchniowe nadawały jej stosunkowo znaczną wytrzymałość i błonowate właściwości. Dodatkowo powłokę tę wzmocniły "tłuszczopodobne substancje (lipidy), wnikające między warstwę wodnego roztworu cząsteczki a warstwę jej wodnej otoczki. Przybrała ona postać lipidowej błony molekularnej charakteryzującej się półprzepuszczalnością, podobnie jak błona biologiczna"44.

Przedstawione przez Ditfurtha procesy przemiany materii miały decydujące znaczenie dla powstania życia, gdyż stworzyły w ziemskiej hydroatmosferze warunki fizykochemiczne sprzyjające pojawieniu się i syntezie związków organicznych. Struktury biotyczne ewoluowały dalej, w kierunku układów zamkniętych i coraz bardziej niezależnych od zmian środowiska. Stanowiły one podstawę i granicę tego, co można już nazwać życiem.

\section{3. ŻYCIE SKUTKIEM SAMOORGANIZACJI MATERII}

Powstawanie cząsteczek organicznych było kolejnym krokiem ewolucji, wprowadzającym ją już na poziom biologiczny. Proces ten miał miejsce mniej więcej 3,5 miliarda lat temu ${ }^{45}$. Przejście następowało stopniowo i nieprzerwanie tak, że niemożliwe jest określenie konkretnej granicy rozdzielającej fazę, która przebiegała w sposób ciąłły od fazy właściwej ewolucji organicznej. Ditfurth przyjmuje przedział czasu pomiędzy 1 a 2 miliardami lat ${ }^{46}$. Traktuje on łącznie: pojawienie się pierwszej komórki oraz jej przekształcenie się w jednostkę stosunkowo niezależną od wpływów zewnętrznych. W zaprezentowany powyżej sposób poja-

${ }^{44}$ Tamże, s. 430-432.

${ }^{45} \mathrm{H}$. von Ditfurth, Na początku byt wodór, s. 279. Ditfurth jest niekonsekwentny w wyznaczaniu tej granicy czasu, gdyż pisze jeszcze o 4 miliardach lat temu - zob. tamże, s. 211; tenże, Nie tylko z tego świata jesteśmy, s. 32. W innych miejscach opowiada się za 3 miliardami lat temu: tenże, Dzieci Wszechświata, s. 17 i 226.

${ }^{46}$ Tenże, Na początku byt wodór, s. 164. 
wiła się na Ziemi komórka - samodzielna i wyposażona w cały zestaw właściwości, umożliwiających jej nie tylko przetrwanie, lecz i przystosowywanie się do zmieniających się warunków środowiskowych. Hoimar von Ditfurth widział jej początki już w samym wydarzeniu powstania Wszechświata. Od chwili wielkiego wybuchu materia ewoluowała, skupiając się i rozpraszając. Jej zmiany prowadziły do coraz doskonalszych tworów. Faza ekspansji kosmicznej wyłoniła galaktyki i gwiazdy, a wokół niektórych z nich planety. Jedna z nich - Ziemia - stała się bezpośrednim środowiskiem, w którym coraz bardziej skomplikowane związki materii nieorganicznej utworzyły materię organiczną.

Hoimar von Ditfurth w swojej koncepcji ukazuje ciągłość procesów ewolucyjnych w stopniowym i bezskokowym przechodzeniu samoorganizacji podstawowych elementów Wszechświata na coraz wyższe poziomy złożoności. Wszechświat miał swój początek i był poddawany zmianom, które doprowadziły do zjawiska życia. Badania naukowe potwierdziły poszczególne etapy przekształceń materii. Jako aksjomat swojej koncepcji, H. von Ditfurth przyjął właściwą materii ciągłą tendencję do łączenia się jednostek elementarnych na każdym szczeblu rozwoju, dającą nowe, złożone jednostki, stanowiące budulec następnego, wyższego szczebla.

\section{POCHODZENIE WSZYSTKICH GATUNKÓW BIOLOGICZNYCH OD JEDNEJ KOMÓRKI}

Naturalne prawa przyrody kierujące siłami Kosmosu, promieniowaniem Słońca i polem magnetycznym Księżyca, utworzyły planetę Ziemia. Miejsce to stało się siedliskiem życia - nowego sposobu istnienia materii. Dokonał się ewolucyjny skok. Wydarzenie to nie było nagłym, nieskoordynowanym wybuchem, tylko naturalną konsekwencją wcześniejszych procesów. Ewolucja fizykochemiczna przygotowała podłoże dla biochemicznych zmian materii. Podstawowym warunkiem tworzącym optymalne dla życia środowisko na Ziemi jest magnetosfera - naturalna osłona podstawowych związków budulcowych życia przed wiatrem słonecznym. Dzięki niej życie bezpiecznie urządziło się w zastanych na Ziemi warunkach: „magnetosfera spełnia w odniesieniu do wiatru słonecznego taką samą funkcję ochrony, jaką wiatr ten spełnia w odniesieniu do nadbiegającego ze Wszechświata promieniowania kosmicznego"47.

\footnotetext{
${ }^{47}$ Tamże, s. 147.
} 
Powstało jakby biopole ochraniające powstające i rozwijające się życie. Występuje tu zatem bezsporna celowość działających powiązań i adaptacji, które utworzyły „kunsztowną i wielokrotnie nawzajem zazębiającą się równowagę i stabilność ziemskiego środowiska"48.

Hoimar von Ditfurth opowiada się za hipotezą, że życie na Ziemi powstało, gdyż ewolucja obdarzona jest tak dużą siłą, że musiała doprowadzić do jego zrodzenia. Po prostu, wykorzystała dwie makrocząstki - białko i kwas nukleinowy - z braku obecności innych w środowisku ziemskim, i z tych biopolimerów (szanse powstania innych polimerów zostały zredukowane) narodziło się życie. Ziemskie warunki sprzyjały formowaniu się białka i kwasów nukleinowych, więc wspomniane polimery powstawały w coraz obfitszych ilościach i gdy na Ziemi pojawiło się życie, jedynym budulcem zdolnym do przekształcania się w wyniku swej złożonej budowy i występującym w dostatecznej ilości były wspomniane dwa rodzaje cząstek ${ }^{49}$. Należy dodać, że ziemska atmosfera wytworzyła specyficzne warunki, które umożliwiły powstanie filtru promieni nadfioletowych ze Słońca, które szybko wyjałowiłyby ziemską powierzchnię. Gęsta powłoka atmosferyczna w wyniku tarcia spalała spadające meteoryty, działając jednocześnie jak magazyn ciepła. Duża część ciepła wypromieniowanego przez Słońce, zatrzymywana na noc, zmniejszała różnice temperatur między dniem a nocą, natomiast prądy termiczne (wiatry) wyrównywały duże różnice temperatur w różnych rejonach Ziemi i przenosiły parę wodną, powodując opady deszczu. Te zjawiska pogodowe wywoływały erozję skał, dzięki czemu powstawała gleba.

\section{PRÓBA POGODZENIA EWOLUCJI I KREACJI: KREACJONIZM EWOLUCYJNY}

Przeprowadzone powyżej analizy wskazują, że ewolucyjna koncepcja H. von Ditfurtha nie wyklucza wszechogarniającego działania Boga, który stworzył świat wraz z rządzącymi nim prawami: „Powstanie złożonego budulca żywych organizmów musiało nastąpić jak gdyby w pewnym stopniu przymusowo, co można wytłumaczyć również bezpośrednią ingerencją jakiejś siły nadprzyrodzonej"50. Zakłada tym

\footnotetext{
48 Tamże, s. 154.

${ }^{49}$ Tenże, Na początku byt wodór, s. 128.

${ }^{50}$ Tamże, s. 132.
} 
samym, że przystosowanie warunków na powierzchni Ziemi do potrzeb pojawiającego się później życia, mogło nastąpić tylko dzięki temu, że wszechmogący Stwórca pozwolił życiu na Ziemi powstać. Istnieje ono dlatego, że samo zjawisko życia posiada tak uniwersalną siłę urzeczywistniania się, iż ewolucja biologiczna mogła rozpocząć się nawet w tak skrajnych i jedynych w swoim rodzaju warunkach, ,jak te, które panowały na pra-Ziemi, gdzie jako punkt wyjścia służyć mogły tylko dwie odpowiednie cząsteczki - białko i kwas nukleinowy"51. Źródłem porządku panującego w tym molekularnym świecie stało się jądro komórki; tam też ze wszystkimi szczegółami znalazł się plan jej budowy i funkcjonowania $^{52}$. Niezbędne informacje zostały zmagazynowane w jądrze komórki w postaci abstrakcyjnych symboli poprzez sekwencje mniejszych jednostek innych jednostek molekularnych - nukleotydów zawierających zasady - w odróżnieniu od aminokwasów należących do białek enzymów. Te łańcuchowe cząsteczki, składające się z nukleotydowych członów, nazwano kwasem nukleinowym ${ }^{53}$. Zawarty w jądrze komórkowym kod genetyczny (kwas dezoksyrybonukleinowy - DNA) jest zapisem w formie szyfru trójkowego ściśle określonych sekwencji aminokwasów ${ }^{54}$. Według tego wzorca komórka zaczęła tworzyć wszystkie potrzebne białka ${ }^{55}$, czyli budulec do odnowienia własnej struktury, a przede wszystkim enzymy ${ }^{56}$. Ponieważ kolejność aminokwasów w enzymie ${ }^{57}$ ustalała jednocześnie ich specyficzną funkcję chemiczna, DNA - za pośrednictwem 64 możliwych kodujących trójek nukleotydowych - decydował w pełnym zakresie nie tylko o budowie, lecz także o wszystkich funkcjach komórki. Trzy zasady - jednostki trójnukleotydowe (tzw. kodony) kodowały jeden spośród

${ }^{51}$ Tamże, s. 134.

${ }^{52}$ Por. W. Dyk, Molekularne aspekty genezy życia. RNA początki życia, w: Wokót biofilozofii Kazimierza Kloskowskiego, red. M. Bała, Pelplin 2004, s. 58-62.

53 Por. L. Orgel, Narodziny życia na Ziemi, tłum. E. Bendyk, „Świat Nauki” 1994, nr 12 , s. $51-58$.

${ }^{54}$ Por. tamże, s. 220.

${ }^{55} \mathrm{O}$ ruchomych modułach genetycznych wykrytych $\mathrm{w}$ białkach, które rozprzestrzeniały się i powielały podczas ewolucji: R. Doolittle, P. Bork, Ewolucyjna ruchliwość modułów białek, tłum. A. Gaciong, „Świat Nauki” 1993, nr 12, s. 36-43.

${ }^{56} \mathrm{O}$ możliwości gromadzenia potrzebnych składników i powielania się cząsteczek: J. Rebek Jr, Syntetyczne samoreplikujące się cząsteczki chemiczne, tłum. E. Bendyk, „Świat Nauki" 1994, nr 9, s. 28-34.

${ }^{57} \mathrm{O}$ kształtowanie się enzymów jako katalizatorów molekularnych: K. Kloskowski, Koncepcja abiogenezy w pracach Reinharda W. Kaplana, w: Z zagadnień filozofii przyrodoznawstwa i filozofii przyrody, t. 5, red. K. Kłósak, Warszawa 1983, s. 123-130. 
dwudziestu aminokwasów, mających służyć jako element budulcowy, a za pomocą czterech różnych zasad możliwe stało się utworzenie łącznie 64 rozmaitych kombinacji, które sprawiły, że pewne aminokwasy były kodowane podwójnie, a nawet potrójnie. Jednocześnie liczba możliwych wariantów dała $20^{100}$ różnych możliwości utworzenia enzymów $\mathrm{z}$ rozmaitymi sekwencjami aminokwasó $\mathrm{w}^{58}$, a tym samym różnorodnymi cechami biologicznymi ${ }^{59}$. W ten sposób, według Hoimara von Ditfurtha, usamodzielniła się pojedyncza komórka jako skutek wymienionej zasady selekcji, a z niej przez ponad 3 miliardy lat udoskonalały się błony komórkowe i inne części składowe komórki ${ }^{60}$, z których ewoluowały następnie wszystkie gatunki ${ }^{61}$.

Niemiecki uczony zakłada, że „ewolucja jest identyczna z aktem stworzenia" ${ }^{\prime 2}$. Stawiając znak równości między ewolucją a historią stworzenia świata, H. von Ditfurth twierdzi, że przyrodnicze poznanie świata nie musi być zasadniczo sprzeczne z religijnymi o nim refleksjami. Dostrzega wręcz wielką szansę, jaką nauki przyrodnicze dają teologom przez pojęcia i obrazy, które współczesnym językiem wyjaśniają zawiłości powstania życia na Ziemi. Nie kryje się przy tym ze swoją wiarą w Boga, stawiając tezę, iż „ewolucja jest identyczna z chwilą aktu stworzenia, że ewolucja kosmiczna i biologiczna stanowią w naszych mózgach projekcje dzieła stworzenia, że historia rozwoju przyrody nieożywionej i ożywionej jest formą, z jakiej «od wewnątrz» przeżywamy stworzenie, które «od zewnątrz», z perspektywy transcendentalnej, a więc naprawdę jest dziełem jednej chwili"'63. Należy podkreślić, że H. von Ditfurth uważa, iż twierdzenie to należy rozumieć dosłownie. $W$ tym miejscu trzeba dodać, że zdolność rozumowania nie jest według niego tylko atrybutem ludzkim, a dążenie do celu i przystosowanie oraz twórcza interwencja, wraz z pamięcią i wyobraźnią, istniały przed powstaniem ludzkiego

${ }^{58}$ Por. tamże, s. 124.

${ }^{59}$ Por. H. von Ditfurth, Na początku byt wodór, s. 222.

${ }^{60}$ Por. J. Horgan, Na początku..., tłum. Z. Markiewicz, „Świat Nauki” 1991, nr 7, s. 25-34.

${ }^{61}$ Por. tamże, s. 228. O zgodności wśród biochemików, że całe życie na Ziemi pochodzi od cząsteczek obdarzonych właściwością samopowielania: G. Joyce, Ukierunkowana ewolucja molekularna, tłum. B. Kamińska, „Świat Nauki” 1993, nr 2, s. 28-35.

${ }^{62} \mathrm{H}$. von Ditfurth, Nie tylko z tego świata jesteśmy, s. 138.

${ }^{63}$ Zob. także: A. Lemańska, Kazimierza Kloskowskiego ewolucyjny model kreacji, w: Wokót biofilozofii Kazimierza Kloskowskiego, s. 87-97. 
mózgu ${ }^{64}$. Według tej koncepcji cały Wszechświat jest rodzajem rozumu, a ludzki mózg jedynie odwzorowuje inteligencję Wszechświata. Ślady ducha, który ukierunkowuje zjawiska przyrody w sposób inteligentny i celowy, H. von Ditfurth dostrzega już u samego prapoczątku natury, kiedy jeszcze nie istniało życie.

\section{TEOLOGICZNO-FILOZOFICZNE ZASTOSOWANIE KREACJONIZMU EWOLUCYJNEGO}

Pewne próby wykorzystania koncepcji Hoimara von Ditfurtha podjął ks. prof. Kazimierz Kloskowski (1953-1999), przejmując od niemieckiego uczonego określenie ewolucji jako chwili aktu stworzenia ${ }^{65}$. Przyjmując materię, czas i przestrzeń jako dane przez Boga, który nawet „nie jest zanurzony w czasie, uznał że dla Boga ewolucja nie istnieje jako proces i może być potraktowana jako swoista chwila aktu stworzenia"66. Zatem z tej perspektywy nie ma kontrowersji między ewolucją a kreacją. Chociaż mechanizmy ewolucji są przypadkowe, to z perspektywy filozoficznej i teologicznej „Pierwsza Przyczyna Sprawcza może być traktowana jako Władca Przypadku”67. Kazimierz Kloskowski stwierdza nawet: „Niewykluczone, że Bóg działający poprzez prawa przyrody jest najwłaściwszą filozoficzno-przyrodniczą perspektywą wyjaśniającą Wszechświat"68. Koncepcję H. von Ditfurtha, przyjmującą działanie Boga poprzez ewolucję, można więc umieścić w nurcie kreacjonizmu ewolucyjnego.

Należy w tym miejscu odnotować, że choć prezentowane w książkach Ditfurtha analizy poświęcone biologicznej teorii ewolucji dostarczają wiele cennego materiału, to jednak nie ustrzegł się on pewnych błędów, o czym pisze Michał Heller ${ }^{69}$. Nie jest prawdą na przykład, że „Einstein udowodnił empirycznie i nieodparcie, że [...] nasza dziedzicznie nabyta aprioryczna wiedza o świecie" ${ }^{\prime 70}$ niedokładnie odpowiada rzeczywistości.

${ }^{64}$ Por. H. von Ditfurth, Na początku byt wodór, s. 35.

${ }^{65}$ Por. K. Kloskowski, Między ewolucja a kreacja, s. 175. Zob. także: A. Lemańska, Kazimierza Kloskowskiego ewolucyjny model kreacji, s. 94.

${ }^{66}$ Tamże, s. 97.

${ }^{67}$ K. Kloskowski, Filozofia ezwolucji i filozofia stwarzania, t. II: Pogodzone bliźniaki. Rzecz o ewolucji i kreacji, Warszawa 1999, s. 73.

${ }^{68}$ Tamże, s. 70.

${ }^{69}$ Por. M. Heller, Nowa fizyka i nowa teologia, Tarnów 1992, s. 137-138.

${ }^{70}$ Por. H. von Ditfurth, Nie tylko z tego świata jesteśmy, s. 178. 
Różne stwierdzenia dotyczące przestrzennej i czasowej nieskończoności Wszechświata ${ }^{71}$ są wysoce nieścisłe i sprzeczne z modelami konstruowanymi przez współczesną kosmologię.

Dopełniając wcześniejsze analizy, trzeba zdecydowanie podkreślić, że kreacja jest terminem filozoficznym, którego treść stanowi prawda o Bogu jako ostatecznej przyczynie wszystkiego. Natomiast termin ewolucja jest typowym pojęciem przyrodniczym, określającym proces pojawienia się nowych gatunków. Podejmując próbę pogodzenia ze sobą kreacji i ewolucji, trzeba sobie uświadomić, że przyrodnicze racje tłumaczące ewolucyjne zmiany kosmosu i życia nie są w stanie odpowiedzieć na pytanie: dlaczego świat istnieje? Odwoływanie się więc tylko do ewolucji nie rozwiązuje problemu genezy świata i życia, który wymaga refleksji filozoficznych, niemożliwych do zweryfikowania przez dane zaczerpnięte z określonych nauk przyrodniczych. W konsekwencji przyjęta teza o twórczej ewolucji jako chwili aktu stworzenia jawi się dla przyrodnika jako powstawanie, tworzenie się czegoś nowego, lepszego. Dla filozofa oznacza zaś ona ewolucję stwórczą, czyli zależność świata i życia w jego istnieniu od Boga, jako od swej przyczyny. Ewolucja domaga się zatem kreacji i w tym sensie potwierdza kreację ${ }^{72}$.

\section{MOŻLIWOŚCl WYKORZYSTANIA KONCEPCJI HOIMARA VON DITFURTHA W PRAKTYCE SZKOLNEJ I KATECHETYCZNO- -PASTORALNEJ}

Słowo Boże nieustannie domaga się przepowiadania, toteż też konieczne jest, aby nie odnoszono mylnego wrażenia konfliktu między wiarą a rozumem. Stąd też współczesna teologia próbuje łączyć wiarę $\mathrm{w}$ stworzenie (kreacjonizm) z teorią ewolucji (ewolucjonizm) ${ }^{73}$. Akt stworzenia Wszechświata $\mathrm{z}$ niczego (łac. creatio ex nihilo i nieustanne jego stwarzanie - łac. creatio continua oraz podtrzymywanie w istnieniu - łac. conservatio mundi) nadaje istnienie stworzone. Jest to proces wyłaniania się całej rzeczywistości z nicości (bez jakiegokolwiek podłoża czy tworzywa) dzięki partycypacji w istnieniu Boga. Tylko nieskończona moc Boga może

${ }^{71}$ Por. tamże, s. 229-230.

${ }^{72}$ Por. K. Kloskowski, Kreacja i ewolucja - próba pewnego uogólnienia, „Miesięcznik Diecezjalny Gdański” 1988, nr 4-6, s. 199.

${ }^{73}$ Por. J. Frankowski, Stworzenie człowieka a ewolucja, „Znak” 1984, nr 7, s. 888-896. 
sprawić zaistnienie czegokolwiek. Byty stworzone, otrzymując istnienie od Bożej wszechmocy, są nieustannie przez Niego stwarzane. Według Objawienia Bożego świat stworzony ma określony początek istnienia i w tym istnieniu jest ustawicznie podtrzymywany. Bez trwania działania stwórczego, wszystko, co jest, obróciłoby się w nicość. Odnosi to do stworzenia całą wizję Boga osobowego - jest rozumnym, wolnym, pełnym miłości, nieprzekazywalnym oraz wszechobecnym i dynamicznym aktem osobowym. Teologia zajmuje się tu celem i sensem stworzenia, które istnieje dla chwały Boga, uczestnicząc w Jego dobru w sposób materialny i przedmiotowy.

Zasadniczo do połowy XIX wieku powszechnie panował pogląd, zgodnie z którym świat i człowiek pojawili się dzięki stwórczym aktom Boga. Gdy jednak w 1859 roku Karol Darwin w swojej pracy O powstawaniu gatunków droga doboru naturalnego zaprezentował odmienne rozwiązanie problemu powstawania świata i człowieka, pojawił się nowy sposób argumentacji na rzecz procesów ewolucji ${ }^{74}$ - już nie filozoficznej, lecz przyrodniczej. Tę przyrodniczą teorię ewolucji traktowano jako niepodważalny dowód zasadności stanowiska filozoficznego zwanego monizmem materialistycznym. Przy pomocy tezy przyrodniczej próbowano uzasadnić poglądy filozoficzne. Taka interpretacja spowodowała, że ewolucjonizm związano z materialistycznym monizmem. Głównym propagatorem takiego podejścia był E. Haeckel, według którego teoria ewolucji daje nie tylko wyczerpujący obraz zjawiska życia, lecz także odnosi się do naturalnych, fizykochemicznych procesów ${ }^{75}$. Z kolei wykorzystanie przez Fryderyka Engelsa koncepcji Darwina do obsesyjnej walki $\mathrm{z}$ teologią ${ }^{76}$ nadało ewolucjonizmowi jeszcze inne piętno. Wytworzył się mianowicie mit niemożności pogodzenia ze sobą prawd religijnych i wyników nauk szczegółowych. Błąd E. Haeckela, polegający przede wszystkim na wyprowadzeniu niewłaściwego wniosku z wypowiedzi K. Darwina na temat ewolucji, że człowiek rozwinął się ze świata zwierząt, został sprowadzony do twierdzenia: "Człowiek nie różni się od zwierzęcia, człowiek jest pewnego rodzaju zwierzęciem"77, a w potocznej opinii przybrał postać: "Człowiek pochodzi od małpy"78.

${ }^{74}$ Zob. K. Darwin, O powstaniu gatunków drogq doboru naturalnego, tłum. S. Dickstein i J. Nusbaum, Warszawa 1955.

${ }^{75}$ Por. E. Haeckel, Natureliche Schöpfungsgeschichte, Berlin 1898, s. 95.

${ }^{76}$ Por. F. Engels, Dialektyka przyrody, Warszawa 1979, s. 9-12.256.

${ }^{77}$ K. Kloskowski, Kreacja i ewolucja - próba pewnego uogólnienia, s. 193.

${ }^{78}$ Już przed K. Darwinem - w XVIII wieku - James Burnett głosił tezę o małpim 
W takiej perspektywie, właśnie zaprezentowana powyżej, z uwagi na charakter opracowania dość ogólnie i syntetycznie, koncepcja powstania życia $\mathrm{H}$. von Ditfurtha, wydaje się niezwykle interesująca i przydatna. Dzięki swojej publicystycznej formie i dbałości o szczegóły naukowe, nadaje się do wykorzystania w praktyce szkolnej i parafialnej: edukacji i katechezie. Autor umie przełożyć abstrakcje nauki na dostępne wyobraźni konkrety, kojarząc ponadto ustalenia nauki z faktami znanymi z życia codziennego. Ewolucyjny model kreacji, stanowiący podstawę dla ewolucyjnej wersji kreacjonizmu chrześcijańskiego, jawi się jako konsekwencja „pogodzenia” ewolucji i kreacji. Może go zaakceptować jako swoisty moment aktu stworzenia w logicznym procesie konfirmacji ewolucji, wyrażającym się nie tyle w udowodnieniu prawdziwości lub fałszywości przyjętej tezy, ile $\mathrm{w}$ ukazaniu pojmowanej przez badacza określonej koncepcji filozofii i nauki ${ }^{79}$. Jedynie teoria „stworzenia z niczego" wyjaśnia w sposób zasadny i ostateczny racjonalność i celowość świata. Tym samym „znosi ostatecznie twierdzenie o niepoznawalności i przypadkowości świata oraz postuluje, że w każdym bycie, wraz z powołaniem go do istnienia, zostały złożone przez Stwórcę myśl i cel"80.

Teoria H. von Ditfurtha, zgodna z kreacjonizmem ewolucyjnym, wydaje się odpowiednią do wyjaśniania biblijnego opisu stworzenia podczas lekcji religii $\mathrm{w}$ szkole i katechezy parafialnej. Właśnie biblijna wiara $\mathrm{w}$ dzieło stworzenia powinna być tematem wszelkiego religijnego kształcenia i nauczania. Mając na uwadze ogólną perspektywę katechetyczną, trzeba uwzględniać wiek grupy, którą się naucza, aby w sposób właściwy i dostosowany do rozwoju psychicznego i religijnego katechizowanych przekazywać niezbędne treści objawienia i realizować zamierzone cele dydaktyczne i wychowawcze ${ }^{81}$. Człowiek w wieku przedszkolnym i szkolnym stopnia podstawowego nie jest jeszcze odpowiednio przygotowany do podjęcia filozoficznej i teologicznej refleksji koncepcji powstania życia - z wszystkimi jej uwarunkowaniami fizykochemicznymi

rodowodzie człowieka, przyjmując ewolucyjne powstanie człowieka wraz ze wszystkimi jego psychicznymi właściwościami. Czynił to z racji filozoficznych, gdyż przyrodniczych nie posiadał: B. Hałaczek, Człowiek w statycznym $i$ dynamicznym pogladzie na świat, "Śląskie Studia Historyczno-Teologiczne" 1974, nr 7, s. 203.

${ }^{79}$ Por. K. Kloskowski, Kreacja i ewwolucja - próba pewnego uogólnienia, s. 205.

${ }^{80}$ A. Maryniarczyk, Creatio ex nihilo, w: Powszechna encyklopedia filozofii, t. 2, red. A. Maryniarczyk, Lublin 2001, s. 318.

${ }^{81}$ Por. A. Läpple, Od egzegezy do katechezy. Stary Testament, t. 1, tłum. B. Białecki, Warszawa 1985, s. 63. 
i molekularnymi. Dopiero na poziomie stopnia ponadpodstawowego (gimnazjalnego i ponadgimnazjalnego) i $\mathrm{w}$ wieku dojrzałym nadarza się jedyna w swoim rodzaju okazja, aby wniknąć w teologiczną głębię i sens chrześcijańskiej wiary $\mathrm{w}$ dzieło stworzenia, zastanowić się nad religijnymi i duchowymi jej konsekwencjami, a także skonfrontować ją ze współczesnymi poglądami na świat. Biblijna wiara w akt stwórczy powinna pomóc $w$ odpowiedzi na pytanie: czy stworzenie świata i jego ewolucyjne rozumienie są do pogodzenia?

\section{IMPLIKACJE PRAKTYCZNE KONCEPCJI HOIMARA VON DITFURTHA: PROPOZYCJA KATECHEZY BIBLIJNEJ}

Nauczanie o stwórczym akcie Boga $\mathrm{w}$ powołaniu do istnienia Wszechświata obejmuje dwa aspekty - z nicości do bytu oraz o podtrzymywaniu go w istnieniu. Ten drugi aspekt oznacza, że Bóg jest Twórcą praw, które rządzą Wszechświatem - nazywanych prawami przyrody. Bóg jest wobec świata transcendentny, a jednocześnie w tajemniczy sposób tym światem kieruje. Nie wyklucza to autonomicznego działania praw przyrody, jednym z których jest też prawo ewolucji. A przecież właśnie Hoimar von Ditfurth, przyznając się do wiary w Boga i sympatyzując z poglądami P. Teilharda de Chardin ${ }^{82}$ - dzięki ogromnej umiejętności przeprowadzania naukowego dowodu bez używania arsenału specjalistycznych narzędzi, nieprzydatnych w ręku człowieka o zbyt ubogim wykształceniu - jest doskonałym przykładem do wykorzystania w praktyce szkolnej i katechetyczno-pastoralnej.

Dzięki odpowiedniej i umiejętnej (kompetentnej) korelacji szkolnego nauczania religii i katechezy parafialnej z nauczaniem fizyki, chemii czy biologii można nie tylko stosować pojęcia znane w tych dziedzinach, ale ukazywać całościowy i spójny pogląd chrześcijański, niesprzeczny ze stanem badań przyrodniczych na temat powstania świata i życia. Dla realizacji tego zadania przydatne są lekcje z wykorzystaniem odpowiednich metod aktywizujących. Właśnie stosowanie wspomnianych metod zmienia rolę katechety z wykładowcy na animatora, który precyzyjnie stawiając zadanie i wskazując metody pracy nad nim, ożywia katechizowanych, płynnie przechodząc od aktywności (kiedy organizuje uczniom

${ }^{82}$ Por. I. Fiut, Ditfurth w drodze na "tamten świat”, "Miesięcznik Literacki" 1987, nr 9, s. 155. 
pracę) do pozornej bierności (kiedy małe grupy pracują, a on uważnie je obserwuje) ${ }^{83}$. Metody te przebiegają według schematu: Prolog, aktywizacja i puenta ${ }^{84}$.

Przykładowy schemat pracy podczas lekcji może wyglądać następująco: We wprowadzeniu katecheta zarysowuje kontekst zadania, tworząc sytuację problemową, aby uczestnicy mogli rozpocząć samodzielne poszukiwania. Na tym etapie warto zaprezentować jedną z książek H. von Ditfurtha i zadać pytanie: czy naukowiec może wierzyć, że Bóg stworzył świat? Część aktywizacyjna - poprzez konkretny wytwór: rysunek, zapis rozwiązań, wypowiedź - ma ukierunkować uczestników na pracę nad postawionym pytaniem. Aktywizację można podzielić na trzy etapy: organizacji pracy przez prowadzącego, pracy w małych grupach i pracy na forum ogólnym. W pierwszym etapie, kiedy wszyscy uczestnicy są już podzieleni na małe zespoły, prowadzący stawia przed nimi zadanie. Czyta tekst, prosząc, aby wsłuchali się w niego pod kątem problemu. Po odczytaniu go powtarza zadanie, aby utrwalić je w pamięci uczestników. Prowadzący dokładnie określa instrukcję dotyczącą pracy - czyli podaje metodę i określa orientacyjny czas pracy w grupach, dostarczając zespołom materiały pomocnicze, np. przez przedstawicieli grup. Na tym etapie można rozdać fragmenty książek H. von Ditfurtha, wyjaśniające występowanie ewolucji na poszczególnych poziomach - fizycznym, chemicznym i molekularnym - oraz teksty Rdz 1,1-2,4a i Rdz 2,4b-25, a następnie zadać pytanie, dotyczące sposobu ewoluowania materii, jak też powstawania świata według opisu biblijnego oraz wniosku autora książki odnośnie możliwego działania siły sprawczej i odpowiednio - wykładni Urzędu Nauczycielskiego Kościoła o interpretacji biblijnego opisu stworzenia.

W drugim etapie uczestnicy czytają tekst, a ich praca zmierza do konkretnego efektu, który zostanie potem zaprezentowany na forum ogólnym ${ }^{85}$. Jej wytworem mogą być - w zależności od metody - wypowiedzi słowne, pisemne, plakaty itd. Uczestnicy mogliby narysować swoje wyobrażenie danego poziomu ewolucji w dziejach Wszechświata. W ostatnim etapie, po podaniu przez prowadzącego instrukcji dotyczącej

${ }^{83}$ Por. Metody aktywizujące w katechezie. Część 1, red. Z. Barciński, Lublin 1999, s. 166 .

${ }^{84}$ Por. Metody aktywizujące w katechezie. Część 3, red. Z Barciński, Lublin 2000, s. $16-17$.

${ }^{85}$ Por. Metody aktywizujące w katechezie. Część 2, red. Z. Barciński, Lublin 1999, s. $18-19$. 
sposobu przedstawienia efektów pracy w grupach, uczestnicy prezentują jej rezultaty.

Wreszcie przychodzi pora na puentę, która jest wyraźną, wyodrębnioną myślą, centralną dla całości sekwencji. $W$ ten sposób prowadzący, odnosząc się do odpowiedzi znalezionych przez uczestników, nadaje sens całości i prowokuje u uczestników przebłysk zrozumienia danej rzeczywistości. Puenty mogą być podsumowujące lub zaskakujące. W podsumowującej chodzi o porządkowanie tego, co uczestnicy wypracowali i wprowadzenie jakiegoś nowego impulsu. Można zastosować tutaj porównanie koncepcji ewolucji do któregoś z dokumentów Magisterium Kościoła o niesprzeczności jej z biblijnym opisem stworzenia. W puencie zaskakującej prowadzący przedstawia myśl, której uczestnicy nie spodziewają się - jest to wskazanie na trudny do podważenia, ale zupełnie nieoczekiwany, aspekt sprawy. Odpowiednim przykładem mogłoby być wyjaśnienie błędności potocznego twierdzenia o ewolucji - że nie wykazuje ono pochodzenia człowieka od małpy, ale że małpa i człowiek mieli wspólnego przodka. Na tej podstawie łatwiej będzie przekonać uczestników do pogodzenia teorii ewolucji z biblijnym opisem aktu stworzenia.

W zaproponowanej powyżej metodzie - na poziomie szkolnym - trzeba uwzględnić zalecenia Komisji ds. Wychowania Katolickiego Konferencji Episkopatu Polski ${ }^{86}$, aby temat korelował z poziomem nauczania szkolnego innych przedmiotów oraz mieścił się $\mathrm{w}$ podstawie programowej nauki religii. Bogactwo scenariuszy i metod aktywizujących jest tak wielkie, że można $\mathrm{z}$ dużą łatwością dowolnie je adaptować do przedstawiania omawianego zagadnienia. Trzeba jednak pamiętać, że podstawową prawdą teologiczną dotyczącą Wszechświata jest to, że został on stworzony przez Boga (koncepcja kreacjonistyczna), a przez to jest w swoim istnieniu całkowicie zależny od Stwórcy i przepojony wartościami. Dla teologii wyjaśnienie świata oznacza usprawiedliwienie jego istnienia, a jedynym możliwym usprawiedliwieniem jest odwołanie się do aktu stworzenia. W tym sensie ewolucja nie tylko nie stoi $\mathrm{w}$ opozycji wobec stworzenia, lecz daje razem z aktem stwórczym „syntetyczny obraz osiągnięty nie przez proste zestawienie, lecz na drodze metodologicznej analizy nauki i teologii" ${ }^{\prime 8}$.

${ }^{86}$ Por. Komisja Episkopatu Polski ds. Wychowania Katolickiego, Program nauczania religii, Kraków 2001. Zob. także: Komisja Episkopatu Polski ds. Wychowania Katolickiego, Dyrektorium katechetyczne Kościoła Katolickiego w Polsce, Kraków 2001.

${ }^{87}$ M. Heller, Nowa fizyka i nowa teologia, s. 120. 


\section{PODSUMOWANIE}

Zwieńczeniem przeprowadzonych analiz jest odpowiedź na zasadnicze pytanie na gruncie filozoficznym i teologicznym o relację między wiarą i rozumem (łac. fides et ratio). Podjęty problem odmiennych koncepcji powstania świata - ewolucyjnej i kreacjonistycznej - mógł początkowo sprawiać wrażenie, iż koncepcje te nie tylko są od siebie oddzielone, ale nawet nawzajem wykluczające i sprzeczne. Jednak dokonane analizy wskazują, że koncepcje przyrodnicze i teologiczne nie tylko nie pozostają ze sobą w sprzeczności, ale można je w pewien sposób zharmonizować i skorelować. Rodzący się $\mathrm{w}$ ten sposób dialog pomiędzy nauką i religią okazuje się nie tylko możliwy i ważny, ale także potrzebny. $\mathrm{W}$ ten sposób, na płaszczyźnie formacji młodego pokolenia - czy to w ramach lekcji religii w szkole, czy to na katechezie parafialnej - można wskazywać bogactwo różnych koncepcji poznania. Błogosławiony Jan Paweł II stwierdził, że „wiara i rozum są jak dwa skrzydła, na których duch ludzki unosi się ku kontemplacji prawdy" (FR, Prolog). Kierując się tym wskazaniem, człowiek może formować się jako osoba w sposób integralny (holistyczny) i harmonijny, to znaczy uwzględniający wszystkie jego sfery - intelektualną, poznawczą, religijną i emocjonalną.

Hoimar von Ditfurth stara się na poziomie filozoficznym określić uniwersalną koncepcję świata i Kosmosu. Jej celem jest przede wszystkim wypracowanie możliwości porozumienia i dialogu ze współczesną metafizyką i teologią w sprawach wyjaśniania początku świata, sposobu jego istnienia, pojawienia się życia oraz człowieka i sensu jego egzystencji. Jest on jednym z budowniczych mostów między wiedzą a wiarą, nauką a religią. Działalność taka odpowiada w pewnym stopniu na tęsknoty współczesnego człowieka skazanego na dysonans poznawczy wywołany wzajemnie niespójnymi przekazami autorytetów naukowych i religijnych. Dlatego krytykuje fundamentalistów kreacjonizmu naukowego, którzy dosłownie interpretują teksty religijne i w poglądzie na świat zupełnie nie liczą się z rezultatami nauk przyrodniczych, jak również witalistów, którzy kierując się ideą samorództwa próbują wysnuć $\mathrm{z}$ rezultatów badań nauk przyrodniczych szereg nieuprawnionych wniosków ${ }^{88}$.

Hoimar von Ditfurth, obserwując świat, doszedł do wniosku, że materia podlega wiecznotrwałej, jednokierunkowej i jednotorowej ewo-

${ }^{88}$ Por. H. von Ditfurth, Nie tylko z tego świata jesteśmy, s. 123. 
lucji, polegającej na osiąganiu coraz większej złożoności, coraz wyższego poziomu organizacji ${ }^{89}$. Ta jednotorowość oznacza, że nie istnieje odrębna droga rozwoju materii martwej i odrębna materii żywej - jest to proces jednolity, który bynajmniej nie dzieje się przypadkowo. W tak rozumianej ewolucji kosmicznej niemiecki lekarz i myśliciel widzi kolejne i konieczne etapy - najpierw powstanie cząstek elementarnych, potem jąder wodo$\mathrm{ru}, \mathrm{z}$ wodoru powstanie atomów wszystkich pierwiastków, następnie obiektów gwiezdnych i ich układów, potem życia i w końcu człowieka. H. von Ditfurth jednocześnie ujawnia ślady inteligentnego i celowego ukierunkowania zjawisk przyrody już u samego prapoczątku natury, gdy jeszcze nie istniało życie. Przebieg ewolucji od momentu prawybuchu aż do powstania życia był według niego celowo ukierunkowany, ponieważ każde kolejne stadium ewolucji, jak już powiedziano, stanowiło punkt wyjścia do stadium następnego, na wyższym poziomie złożoności. Można zatem próbować dowodzić, że taki proces kosmiczny nie mógł powstać przypadkowo ${ }^{90}$.

Właśnie te twierdzenia okazują się czynnikiem ubogacającym na gruncie edukacji i katechezy, gdyż doprowadzają do wzajemnych implikacji pomiędzy wiarą (łac. fides) a rozumem (łac. ratio). To w szkole dochodzi do bezpośredniego spotkania nauki, kultury i religii. Stąd też analiza koncepcji Hoimara von Ditfurtha może znacząco przyczynić się do uatrakcyjnienia prowadzonych zajęć, jak też do podniesienia ich rangi i poziomu. Tym sposobem może dojść do swoistej realizacji postulatu św. Anzelma z Canterbury (1033-1109), aby wiara była rozumna, zaś rozum oświecony wiarą. By mogło do tego dojść (pogodzenie ewolucji z wykładnią wiary katolickiej oraz uatrakcyjnienie zajęć), konieczne jest (łac. conditio sine qua non) gruntowne przygotowanie nauczycieli (wykształcenie formalne), zgodnie ze słowami umieszczonymi nad wejściem do Akademii Platońskiej w starożytnych Atenach: niech nie wstępuje ten, kto się nie zna na geometrii (gr. ageometretos medeis eisito). Należy wyrazić nadzieję, że zaproponowane rozważania oraz biblijna metoda aktywizująca staną się inspiracją do powstawania scenariuszy i innowacji na płaszczyźnie edukacyjno-formacyjnej, aby poznanie człowieka było otwarte na Boga i Jego nieustanne działanie w miłości.

\footnotetext{
89 Por. M. Iłowiecki, Śladami kosmicznej ewolucji, „Odra” 1979, nr 12, s. 25.

${ }^{90}$ Por. S. Budzyński, Teologia w oczach przyrodnika, s. 5.
} 


\section{PEDAGOGICAL AND RELIGIOUS EDUCATION POSSIBILITIES OF APPLYING HOIMAR VON DITFURTH'S THEORY OF THE CREATION OF LIFE}

\section{SUMMARY}

Who am I? Where do I come from and where am I going to? - these are universal and timeless existential questions, the answers to which have been searched for by people down the centuries. That is why the issue of the creation of life and the beginnings of man (abiogenesis and anthropogenesis) is constantly on the minds of many people - both philosophers and theologians. It is not surprising that with time numerous solutions to this question have been found, both in the area of evolutionism (natural) and creationism (theological). One concept that stands out among them is the theory of a German professor of psychiatry and neurology - Hoimar von Ditfurth (1921-1989), who tried to build a universal concept of the Universe on a philosophical level.

Hoimar von Ditfurth's evolutionary creationism assumes that all matter undergoes everlasting, uni-directional evolution, which aims at increasing complexity. This process is uniform, deliberate and it has sense. Hoimar von Ditfurth's research led to the creation of the universal concept of the world and the Cosmos, and to the possibility of a dialogue between creationism and evolutionism, between abiogenesis and anthropogenesis, between modern metaphysics and theology. He proves that it is not possible that the whole cosmic process is only an accident. The fact that this original view reconciles the biblical thought with philosophical reflection and scientific experience is what makes it important, particularly in pedagogical, theological and religious instruction and pastoral areas. Hoimar von Ditfurth's concept can enrich education and evangelization because school is the place where the direct meeting between science, culture and religion takes place. 